\title{
KEBEBASAN BERKONTRAK DALAM PEMBIAYAAN MUSYARAKAH DI KSPPS BMT LARIBA ISLAMIC CENTRE CIREBON
}

\author{
Vina Gunawan dan Didi Sukardi \\ Institut Agama Islam Negeri Syekh Nurjati Cirebon \\ Email:vinagunawan11@gmail.com dan didisukardimubarrak@gmail.com
}

\begin{abstract}
This study examines the Musyarakah financing contract is implemented at KSPPS BMT Lariba Islamic Center, the principle of freedom of contract is applied to the Musyarakah financing contract according to positive law, and Islamic law's points of view of the application of the principle of freedom of contract in Musyarakah financing contracts. This research is a field research using descriptive qualitative research methods as well as empirical normative. The results of the study indicate that the Musyarakah financing contract applied at KSPPS BMT Lariba Islamic Center is valid because the pillars and contract conditions in Islamic law have been fulfilled. The application of the principle of freedom of contract in the overall financing contract is in accordance with the Civil Code in book III article 1380 concerning freedom of contract. The application of the principle offreedom of contract does not contain a loss-sharing clause. Losses on musharaka financing must be divided proportionally according to the respective capital.
\end{abstract}

Keywords: Contract, Financing, and Musyarakah.

\begin{abstract}
Abstrak
Penelitian ini mengkaji mengenai akad pembiayaan musyarakah yang diterapkan di KSPPS BMT Lariba Islamic Centre, bagaimana penerapan asas kebebasan berkontrak pada akad pembiayaan musyarakah menurut hukum positif, dan pandangan hukum Islam terhadap penerapan asas kebebasan berkontrak pada akad pembiayaan musyarakah. Penelitian ini merupakan penelitian lapangan dengan menggunakan metode penelitian deskriptif kualitatif serta bersifat normatif empiris. Hasil penelitian menunjukkan bahwa akad pembiayaan musyarakah yang diterapkan di KSPPS BMT Lariba Islamic Centre sah karena telah terpenuhinya rukun dan syarat-syarat berkontrak dalam hukum Islam. Penerapan asas kebebasan berkontrak pada akad pembiayaan keseluruhannya sesuai menurut KUH Perdata dalam buku III pasal 1380 tentang kebebasan berkontrak. Penerapan asas kebebasan berkontrak tidak terdapat klausul pembagian kerugian. Kerugian pada pembiayaan musyarakah harus dibagi secara proporsional menurut modal masing-masing.
\end{abstract}

Kata Kunci: Kontrak, Pembiayaan, dan Musyarakah. 


\section{PENDAHULUAN}

Salah satu bidang muamalat yang mengalami perkembangan cepat adalah masalah perjanjian atau kontrak. Penyebab utama pesatnya perkembangan perjanjian adalah karena adanya asas kebebasan berkontrak, yaitu memberikan kebebasan bagi setiap orang untuk mengadakan perjanjian apapun dan bagaimana jenis dan isinya, baik yang sudah diatur atau belum diatur dalam undang-undang (Rusydi, 2018). Wujud perjanjian haruslah dibangun atas dasar konsensus yang lahir dari kebebasan berkehendak dari para pihak yang hendak memasuki suatu perjanjian. Pentingnya penekanan sebuah perjanjian yang lahir dari wujud konsensus kebebasan berkehendak para pihak, maka tentu saja suatu perjanjian yang terbentuk tidak boleh ada unsur paksaan atau penyalah gunaan keadaan dari salah satu pihak yang merugikan pihak lain. Bila itu terjadi, konsekuensinya perjanjian dapat dibatalkan. Dapat dibatalkannya perjanjian karena faktor paksaan ataupun penyalahgunaan keadaan, tidak lain merupakan kehendak untuk melindungi pihak-pihak yang kepentingannya dirugikan dalam perjanjian (Raharjo dan Seda, 2009: 99). Wujud konsensus kebebasan berkehendak para pihak dalam kontrak itu, kemudian terkristalisasi dalam suatu asas yang dikenal dengan nama asas kebebasan berkontrak. Bahwa asas kebebasan berkontrak menyatakan seseorang pada umumnya memiliki pilihan bebas untuk mengadakan perjanjian.

Kebebasan membuat perjanjian menjadikan orang dapat menciptakan hakhak perseorangan yang diatur dalam Buku III Kitab Undang-undang Hukum Perdata akan tetapi diatur sendiri dalam perjanjian, sebab perjanjian yang dibuat secara sah berlaku sebagai undang-undang bagi mereka yang membuatnya (pasal 1338 ayat (1) Kitab Undang-Undang Hukum Perdata) Namun kebebasan berkontrak bukan berarti boleh membuat kontrak (perjanjian) secara bebas, tetapi kontrak (perjanjian) harus tetap dibuat dengan mengindahkan syarat-syarat untuk sahnya perjanjian, baik syarat umum sebagaimana disebut pasal 1320 Kitab Undang-Undang Hukum Perdata maupun syarat khusus untuk perjanjian-perjanjian tertentu.

Hukum perjanjian Islam mengenal asas kebebasan berkontrak, yaitu kebebasan untuk membuat akad baru yang belum pernah dirumuskan oleh para fuqaha atau berisikan sejumlah klausula-klausula baru yang mencerminkan kepentingan masingmasing pihak. Dengan catatan dilakukan secara suka rela serta tidak termasuk larangan syara (Anwar, 2010). Adanya ketidak seimbangan kedudukan para pihak dalam suatu perjanjian, sering menyebabkan anggotaa akan mengalami keadaan yang kurang menguntungkan. Kontrak baku yang disandingkan dengan akad musyarakah adalah akad yang memerlukan musyawarah, akan menyebabkan ketidakselarasan dan ketidakadilan.

Problematika ini akan berdampak pada anggota KSPPS BMT Lariba Islamic Centre akan merasa dirugikan atas kontrak yang dibuat secara sepihak (contract standart) tersebut. Karena itu, pihak KSPPS BMT Lariba Islamic Centre perlu memberitahukan mengenai adanya negosiasi terhadap perjanjian kontrak pada akad musyarakah. Dengan demikian berdasarkan alasan-alasan yang telah dikemukakan diatas, untuk itu maka peneliti merasa perlu untuk mengkaji lebih dalam lagi mengenai: 1) bagaimana akad pembiayaan musyarakah yang diterapkan di KSPPS BMT Lariba Islamic Centre, 2) bagaimana penerapan asas kebebasan berkontrak pada akad pembiayaan musyarakah di KSPPS BMT Lariba Islamic Centre menurut hukum positif, 3) bagaimana pandangan hukum Islam terhadap penerapan asas kebebasan berkontrak pada akad pembiayaan musyarakah di KSPPS BMT Lariba Islamic Centre.

\section{LITERATUR REVIEW}

Dalam penelitian terdahulu digunakan untuk membantu mendapatkan gambaran dalam menyusun mengenai penelitian ini. Adapun 
penelitian terdahulu yang telah membahas topik ini, yaitu Pertama Jurnal Ibnu Rusydi, yang berjudul Asas Kebebasan Berkontrak Dalam Pembiayaan Mudharabah Pada Perbankan Syari'ah. Adapun permaslahan yang dipaparkan kebebasan membuat kontrak terkadang menjadi suatu sarana untuk mengetahui keinginan para pihak serta kerelaan dan kesepakatan di antara mereka. Sementara di Perbankan Syariah, kebebasan berkontrak diterapkan untuk menarik nasabah sebanyak banyaknya. Kontrak baku yang disandingkan dengaan akad mudharabah yang notabennya adalah akad yang memerlukan musyawarah, menyebabkan ketidak selarasan dan ketidakadilan. Problematika ini akan berdampak pada kehidupan nasabah, di mana nasabah akan merasa dirugikan atas kontrak yang dibuat secara sepihak. Persamaan penelitian ini dengan penelitian peneliti adalah sama-sama membahas asas kebasan dalam berkontrak. Perbedaan dalam penelitian ini akad pembiayaan serta tempat penelitian (Rusydi, 2018).

Kedua, Jurnal Arief Ikhsanto, yang berjudul Studi Komparatif Asas Kebebasan Berkontrak Dalam Jual Beli Menurut Kitab Undang-undang Hukum Perdata Dan Kompilasi Hukum Ekonomi Syariah. Adapun penelitian ini membahas perbandingan perjanjian bagi hasil menurut Kitab Undang-undang Hukum Perdata dengan akad musyarakah menurut Undangundang Perbankan Syariah serta mengetahui faktor-faktor yang menyebabkan akad musyarakah di perbankan syariah masih memerlukan aturan yang termuat dalam Kitab Undang-undang Hukum Perdata. Di antara persamaannya adalah bahwa keduanya sama-sama lahir dari asas kebebasan berkontrak yang berdasar pada Pasal 1338 Kitab Undang-undang Hukum Perdata. Pembeda yang paling utama antara keduanya adalah pembeda akad pembiayaan musyarakah, tempat penelitian serta presepektif yang digunakan dalam peneliti leih kepada madzhab Syafi'I (Ikhsanto, 2015).
Ketiga, Skripsi Khoiru Safingi, Prodi Muamalat, Universitas Islam Negeri Sunan Kalijaga Yogyakarta, 2009 yang berjudul Penerapan Asas Kebebasan Berkontrak Dalam Akad Pembiayaan di BMT Mitra Usaha Insani. Skripsi ini berisi tentang sistem kebebasan berkontrak pada akad pembiayaan dalam hukum Islam dimana suatu praktek yang sudah biasa berlaku diantara para pihak secara otomatis akan mengikat para pihak. Para pihak tersebut dapat mengasosiasikan segala syarat kontrak termasuk syarat penerapan kebiasaan setempat yang berlaku dan juga dapat merumuskan penerapan kebiasaan tersebut, termasuk kebiasaan yang berkembang dalam sektor perdagangan. Persamaan penelitian ini dengan peneliti bahas adalah sama-sama membahas asas kebasan dalam berkontrak. Perbedaan dalam penelitian ini dengan penelitian peneliti sendiri adalah pembiyaannya secara umum, sedangkan peneliti membahas lebih spesifik yaitu tentang pembiayaan musyarakah serta hukum Islam yang digunakan peneliti lebih mengerucut lagi yaitu pandangan Imam AsSyafi' I (Safingi, 2009).

Keempat, Penelitian Skripsi Sigit Santoso, Prodi Ilmu Hukum, Universitas Islam Negeri Sunan Kalijaga Yogyakarta, 2015 yang berjudul Penerapan Asas Kebebasan Berkontrak Pada Perjanjian Pemborongan. Skripsi ini membahas tentang (Studi Kasus Pelaksanaan Perjanjian Rehabilitasi Jalan Simpang Sedayu, Kemusuk Lor, Kecamatan Sedayu, Kabupaten Bantul). Yang membahas mengenai kegiatan pembangunan jalan merupakan salah satu alternatif untuk memperlancar arus tranportasi dari satu daerah ke daerah lainnya. Untuk itu dari tahun ke tahun Pemerintahan Kabupaten Bantul akan terus melakukan kegiatan pembangunan jalan agar Kabupaten Bantul dapat terus berkembang terutama dari segi pembangunan infrastruktur daerahnya.Untuk melakukan kegiatan pembangunan rehabilitasi peningkatan jalan ini tentunya tidak mungkin dilakukan sendiri oleh Pemerintah Kabupaten Bantul tanpa 
keterkaitan pihak lain. Maka melalui Dinas Pekerjaan Umum Kabupaten Bantul diadakanlah pelelangan untuk mencari kontraktor pelaksana yang dapat melakukan kegiatan pembangunan jalan ini. Adapun masalah pokok dalam penelitian ini adalah Bagaimana Pelaksanaan Penerapan Asas Kebebasan Berkontrak Pada Perjanjian Pemborongan Dalam Pembangunan Rehabilitasi Jalan Simpang Sedayu antara Dinas Pekerjaan Umum Kabupaten Bantul Dengan PT. Maju Sarana Mulya. Apakah sepenuhnya terpenuhi atau tidak asas kebebasan berkontrak pada perjanjian pemborongan tersebut. Persamaan penelitian ini dengan penelitian peneliti membahas asas kebasan dalam berkontrak. Perbedaan dalam penelitian ini dengan penelitian peneliti bahas terletak pada kontrak perjanian kerja sedangkan peneliti membahas kontrak pembiayaan serta tempat penelitian yang berbeda (Santoso, 2015).

Kelima, Skripsi dari Rizki Khairunisa yang berjudul Penerapan Asas Bebas Berkontrak Dalam Akad Murhabahah di BMT Al-hasanah Sekampung. Skripsi ini mengkaji tentang kontrak. Penyebab utama pesatnya perkembangan perjanjian adalah karena adanya asas kebebasan bekontrak, yaitu memberikan kebebasan bagi setiap orang untuk mengadakan perjanjian apapun dan bagaimana jenis dan isinya, baik yang sudah diatur atau belum diatur dalam undang-undang. Namun tidak bisa dipungkiri, bahwa dalam prakteknya pembuatan akad atau perjanjian di Lembaga Keuangan khususnya Lembaga Keuangan Syariah tidak jarang ditemukan akad baku atau kontrak baku yang didalamnya telah ditentukan isinya oleh pihak Lembaga Keuangan secara sepihak dan anggota hanya tinggal menyetujui isi akad atau perjanjian tersebut. Persamaan penelitian ini dengan penelitian peneliti bahas adalah sama-sama membahas penerapan asas kebasan dalam berkontrak. Perbedaan dalam penelitian ini terletak dalam akad yang digunakan serta objek atau tempat penelitian (Khairunisa, 2018: 37).

\section{METODE PENELITIAN}

Penelitian ini merupakan penelitian lapangan (field research) dengan menggunakan metode penelitian deskriptif kualitatif serta bersifat normatif empiris. Sumber data primer diperoleh dari penelitian di lapangan melalui wawancara kepada pihak KSPPS BMT Lariba Islamic Centre. Sumber data sekunder diperoleh melalui buku, jurnal, peraturan perundang-undangan, dokumen, dan laporan penelitian terkait kontrak buku pembiayaan akad musyarakah.

Analisis data penelitian ini menggunakan metode analisis kualitatif artinya menguraikan data yang diolah secara rinci kedalam bentuk kalimat-kalimat deskriptif, analisis yang dilakukan bertitik tolak dari analisis empiris yang dalam pendalamannya dilengkapi dengan analisis normatif. Berdasarkan hasil analisis ditarik kesimpulan secara dedukatif, yaitu cara berpikir yang didasarkan pada fakta-fakta yang bersifat umum untuk kemudian ditarik suatu kesimpulan bersifat khusus.

\section{KONSEP DASAR}

\section{Hukum Kontrak Positif}

Hukum kontrak merupakan bagian dari hukum perikatan. Bahkan sebagian ahli hukum menempatkan sebagai bagian dari hukum perjanjian karena kontrak sendiri ditempatkan sebagai perjanjian kontrak tertulis. Hukum kontrak merupakan terjemahan dari bahasa Inggris, yaitu contract of law, sedangkan dalam bahasa Belanda disebut dengan istilah overeenscomstrecht (Djamil, 2013: 11-12). Perikatan adalah perhubungan hukum antara dua orang atau dua pihak, berdasarkan mana pihak yang satu berhak menuntut sesuatu hal dari pihak yang lain, dan pihak yang lain berkewajiban untuk memenuhi tuntutan tersebut. Hukum Kontrak merupakan salah satu bidang kajian hukum yang selalu berkembang seirama dengan perkembangan masyarakat.

Faktor penyebab tumbuh dan berkembangnya hukum kontrak adalah karena pesatnya kegiatan bisnis yang 
dilakukan dalam masyarakat modern dan pesatnya transkasi yang dilakukan oleh pemerintah dengan pihak lainnya baik pemerintah pusat maupun pemerintah daerah. Faktor lain dari penyebab tumbuh dan berkembangnya hukum kontrak adalah karena adanya asas kebebasan berkontrak, sebagaimana yang diatur dalam Pasal 1338 KUH Perdata bahwa kebebasan itu yang meliputi kebebasan untuk membuat perjanjian, mengadakan kontrak dengan siapapun, menentukan isi kontrak, pelaksanaan dan persyaratan serta menentukan bentuk kontrak yaitu lisan atau terrulis. Artinya hukum kontrak adalah aturan hukum yang berkaitan dengan pelaksanaan perjanjian atau persetujuan.

Kebebasan berkontrak merupakan salah satu asas yang sangat penting, karena merupakan wujud dari hak manusia. Karena pada dasarnya manusia secara individu mempunyai Hak bebas untuk melakukan dan atau tidak melakukan sesuatu (Ahmadi, 2010). Asas kebebasan berkontrak dapat dianalisis dari ketentuan Pasal 1338 ayat (1) KUH Perdata, yang berbunyi: "semua perjanjian yang dibuat secara sah berlaku sebagai undang-undang bagi mereka yang membuatnya."

Tiap-tiap individu manusia mempunyai kebebasan dalam membuat suatu kontrak atau perikatan tanpa adanya ssesuatu hal yang membatasi atau menghalangi, kecuali diatur demikian oleh undang-undang. Asas kebebasan berkontrak adalah suatu asas yang memberikan kebebasan kepada para pihak untuk: membuat atau tidak membuat perjanjian, mengadakan perjanjian dengan siapa pun, menentukan isi perjanjian, pelaksanaan, dan persyaratannya, serta menentukan bentuk perjanjiannya apakah tertulis atau lisan.

Kitab Undang-undang Hukum Perdata mengatur bahwa perjanjian dianggap sah dan mengikat jika telah dicapai kesepakatan antar para pihak. Meski demikian, terdapat pengecualian atas asas konsensualisme, yaitu perjanjian dianggap sah dan mengikat jika dilakukan secara formil berdasarkan ketentuan yang ditetapkan menurut undang-undang (Rosyid, 2017: 33). Dalam hukum positif, asas konsensualisme mengacu pada Kitab Undang-undang Hukum Perdata khususnya Pasal 1320 yang mengatur: "Untuk sahnya suatu perjanjian diperlukan empat syarat: sepakat mereka yang mengikatkan dirinya, kecakapan tuntuk membuat perikatan, suatu hal tertentu, suatu sebab yang halal. Asas ini menyatakan bahwa segala transaksi yang dilakukan harus atas dasar kerelaan antara masing-masing pihak. Bentuk kerelaaan dari para pihak tersebut telah wujud pada saat terjadinya kata sepakat tanpa perlu dipenuhinya formalitas-formalitas tertentu. Apabila syarat pertama dan kedua tidak terpenuhi, maka perjanjian dapat dibatalkan. Artinya, salah satu pihak dapat mengajukan kepada penadilan untuk membatalkan perjanjian yang telah disepakatinya. Akan tetapi, apabila para pihak tidak ada yang keberatan, maka perjanjian tetap dianggap sah. Apabila syarat ketiga dan keempat tidak terpenuhi, maka perjanjian itu batal demi hukum. Artinya, dari semula perjanjian itu dianggap tidak ada.

Adanya asas kebebasan berkontrak, sebagaimana yang diatur dalam Pasal 1338 Kitab Undang-undang Hukum Perdata bahwa kebebasan itu yang meliputi kebebasan untuk membuat perjanjian, mengadakan kontrak dengan siapapun, menentukan isi kontrak, pelaksanaan dan persyaratan serta menentukan bentuk kontrak yaitu lisan atau terrulis. Artinya hukum kontrak adalah aturan hukum yang berkaitan dengan pelaksanaan perjanjian atau persetujuan (Salim, 2013: 10).

Berakhirnya kontrak merupakan selesai atau hapusnya sebuah kontrak yang dibuat antara dua pihak, yaitu pihak kreditur dan debitur tentang suatu hal, pihak kreditur adalah pihak atau orang yang berhak atas suatu prestasi, sedangkan debitur adalah pihak yang berkewajiban untuk memenuhi prestasi. praktik dikenal pula cara berakhirnya kontrak, yaitu: jangka waktunya berakhir, dilaksanakan objek perjanjian, 
kesepakatan kedua belah piak, pemutusan kontrak secara sepihak oleh salah satu pihak, dan adanya putusan pengadilan (Salim, 2013: 165).

\section{Hukum Kontrak Prespektif Hukum Islam}

Prespektif Hukum Islam Terhadap Penerapan Asas Kebebasan Berkontrak pada Akad Pembiayaan Musyarakah di KSPPS BMT Lariba Islamic Centre Imam presepektif Imam Asy-Syafi'i asas kebebasan berkontrak adalam fikih Islam mencakup dua aspek, yaitu pertama kebebasan mengadakan akad dan sisi keridhaannya (hurriyatu at-Ta'aqqud wa ridhaiyyatih), yang kedua yaitu, kebebasan mengadakan syarat dan sisi keridhaannya (hurriyatu al-Isytirath wa tartib atsar alAqd) (Salim, 2013: 11).

Kontrak dalam terminologi Islam diistilahkan dengan al-`aqd (jamaknya $a l$ uqud). Secara etimologis kata $a l$ - ${ }^{\prime} a q d$ berarti perikatan, perjanjian dan pemufakatan. Kata tersebut telah diserap dan dijadikan sebagai bahasa baku dalam bahasa Indonesia menjadi akad. Kontrak termasuk masalah mu`amalat dan keduniaan sehingga akad hukumnya diperbolehkan. Namun dengan syarat akad tersebut telah menjadi kesepakatan para pihak yang berkompeten (terikat) dalam perjanjian tersebut sebagaimana yang dinyatakan oleh kaedah kedua. Untuk itu kaum muslimin tanpa ada pengecualian, pada dasarnya bebas melakukan akad selama tidak ada dalil yang melarang atau mengharamkannya. Batas kebebasan berkontrak dalam hukum Islam (Anwar, 2010).

Berdasarkan ketentuan penetapan atau pelembagaan kebebasan berkontrak di atas,dapat ditarik bahwa berkontrak pada dasarnya boleh (mubah) selama tidak mengandung sifat mengambil harta orang lain dengan cara bathil. Memberikan kebebasan kepada para pihak untuk melakukansuatu perikatan. Bentuk dan isi perikatan tersebut ditentukan ditentukanoleh para pihak. Apabila telah disepakati bentuk dan isinya, maka perikatan tersebut mengikat para pihak yang menyepakatinya dan harus dilaksanakan segala hak dan kewajibannya. Namun kebebasan ini tidak absolut, sepanjang tidak bertentangan dengan syari'ah Islam maka perikatan tersebut boleh dilaksanakan (Al-Zuhayli, 1989: 192).

$$
\text { Syari'at Islam memberikan }
$$

kebebasan kepada setiap orang yang melakukan akad sesuai dengan yang diinginkan, tetapi yang menentukan syarat sahnya adalah ajaran agama. Syarat kebebasan dalam asas bebas kontrak terdapat Akad yang sah sebagaimana yang disepakati dalam perjanjian, tidak mengandung unsur gharar, dilakukan di bawah ikrah atau paksaan, tipuan, dan ghubn atau penyamaran. Jika syarat-syarat ditentukan secara sepihak, sedangkan pihak lainnya terpaksa menerima apa adanya maka perlu diadakan pengawasan oleh pemerintah dalam penetapan aturanaturan dasar yang harus ditaati dalam pembuatan perjanjian baku demi menegakkan keadilan dan menghindari gharar yang dapat merugikan salah satu pihak (Supramono, 2009: 54).

\section{Pembiayaan Musyarakah}

Pengertian pembiaayan sebagaimana yang telah ditetapkan dalam keputusan Menteri Koperasi Usaha kecil dan Menengah No. 91 tahun 2004 yang menyatakan bahwasanya pembiayaan adalah kegiataan penyediaan dana untuk investasi atau kerjasama permodalan antara pihak koperasi dengan anggota, yang mana mewajibkan penerima pembiayaan itu wajib untuk melunasi pokok pembiayaan yang diterima kepada pihak koperasi sesuai akad disertai dengan pembiayaan sejumlah bagi hasil dari suatu pendapatan atau laba dari kegiataan yang dibiayai atau pengunaan dana tersebut (Syafei, 2001: 183).

Musyarakah, syarikah atau syirkah menurut bahasa memiliki makna al-ikhtilath yang artinya campur atau percampuran. Berdasarkan wawancara dengan Ibu Halimah, selaku Customer Service KSPPS BMT Lariba Islamic Centre, maksud dari percampuran yakni seseorang 
mencampurkan hartanya dengan harta orang lain sehingga antara bagian yang satu dengan lainnya sulit untuk dibedakan. Dalam menjalankan musyarakah terdapat konsep wakalah, yaitu setiap pemegang saham (mitra) pada dasarnya mempunyai hak untuk mengelola usaha/aset syirkah tersebut dengan sendirirnya, tetapi bagi pihak-pihak yang tidak dapat meakukannya dapat memeberikan wakil kepada pemegang saham lain atau pihak lain, dengan syarat orangg yang diwakilkan tersebut berkompoten untuk menjadi wakil sesuai dengan hak dan kewenangan.

Kata syirkah dalam bahasa arab berasal dari kata syarika (fi'il madhi), yashruku (fi'il mudhari) syarikan atau syirkatan atau syarikatan (masdar atau kata dasar), artinya menjadi sekutu atau syarikat (kamus al-Munawar). Menurut arti asli bahasa Arab, syirkah berarti mencampurkan dua bagian atau lebih sehingga tidak boleh dibedakan lagi satu bagian dengan bagian lainnya. Al-Musyarakah adalah akad kerja sama antara dua pihak atau lebih untuk suatu usaha tertentu dimana masing-masing pihak memberikan kontribusi dana atau amal atau expertise dengan kesepakatan bahwa keuntungan dan risiko akan ditanggung bersama sesuai dengan kesepakatan (Syafei, 2001: 185).

Akad musyarakah telah memiliki fatwa dari Dewan Syariah Nasional (DSN) MUI yaitu pada Fatwa DSN No: 08/DSNMUI/IV/2000. Fatwa tersebut dikeluarkan atas beberapa pertimbangan diantaranya: Kebutuhan masyarakat untuk meningkatkan kesejahteraan dan usaha terkadang memerlukan bantuan dari pihak lain yang mana itu bisa tercapai dengan salah satu caranya adalah musyarakah. Pembiayaan musyarakah nyatanya memiliki keunggulan baik dari segi kebersamaan juga dalam hal keadilan. Bila cara-cara tersebut dapat disesuaikan dengan syariah maka DSN perlu menetapkan fatwa tentang musyarakah agar bisa menjadi pedoman lembaga keuangan syariah (LKS) (Setiawan, 1979: 15).

\section{PEMBAHASAN DAN DISKUSI}

\section{Akad Pembiayaan Musyarakah KSPPS BMT Lariba Islamic Centre}

Perkembangan bisnis lembaga keuangan yang semakin cepat, KSPPS BMT Lariba Islamic Centre dalam pembuatan perjanjian simpanan maupun tidak melibatkan calon anggota sudah biasa terjadi. Perjanjian tersebut dalam bentuk draf atau formulir yang telah disiapkan oleh pihak pertama atau pihak lembaga pembiayaan, kemudian draf tersebut diserahkan kepada calon nasabah sebagai pihak kedua dengan prinsip take it or leave it atau biasa disebut sebagai perjanjian baku. Pihak kedua tidak dapat mengajukan usulan, masukan maupun keberatan terhadap isi pada formulir tersebut.

Ketentuan sudah di standarisasi atau dibakukan oleh pihak lembaga. Artinya pihak pertama yaitu calon anggota yang ingin melakukan akad pembiayaan tidak ikut serta dalam pembuatan kontrak. Berdasarkan wawancara dengan Ibu Halimah selaku Customer Service KSPPS BMT Lariba Islamic Centre, pihak anggota hanya diberi kesempatan untuk membaca dan memahami isi dari kontrak musyarakah tersebut, baik dari segi syarat-syarat dan ketentuanketentuannya maupun konsekuensi yang sewaktu-waktu akan timbul. Hal ini bertujuan untuk mengefisiensikan waktu pembuatan kontrak. Namun asas kebebasan berkontrak dalam kontrak baku yang telah ditetapkan oleh pihak pertama atau pihak lembaga tetap menggunakan asas kebebasan berkontrak. Dimana kedua belah pihak dapat bernegosiasi mengenai jangka waktu pelunasan pembiayaan yang akan dijalani oleh pihak kedua dan calon pihak kedua pun dibebaskan untuk membaca dan memahami isi kontrak yang telah dibuat oleh pihak pertama untuk melanjutkan pihak kedua bebas apakah ingin melanjutkan kontrak tersebut ataupun tidak melanjutkan kontrak tersebut. Jadi, menurut Bapak Sidik selaku Manager KSPPS BMT Lariba Islamic Centre, dalam proses perjanjian tersebut tidak ada paksaan dari pihak manapun. 
Secara yuridis, perjanjian memberikan kebebasan seluas-luasnya kepada masyarakat untuk mengadakan perjanjian yang berisi apa saja asalkan tidak melanggar ketertiban umum dan kesusilaan. Hal ini berarti bahwa pihak yang mengadakan perjanjian diperbolehkan membuat ketentuan-ketentuan sendiri yang menyimpang dari pasal-pasal hukum perjanjian dan mereka diperbolehkan mengatur sendiri kepentingan mereka dalam perjanjian yang mereka adakan.

Hal ini sesuai dengan asas kebebasan berkontrak yang disimpulkan dari pasal 1338 Kitab Undang-undang Hukum Perdata yang berbunyi "semua perjanjian yang dibuat secara sah berlaku sebagai undang-undang bagi mereka yang membuatnya". Dari kata"semua"dapat ditafsirkan bahwa setiap subjek hukum dapat membuat perjanjian dengan isi apapun, untuk itu ada kebebasan subjek hukum untuk menentukan bentuk perjanjian atau membuat perjanjian.

Kebebasan berkontrak telah diakui dan dianut sebagai suatu asas di dunia pada umumnya. Sehingga asas kebebasan berkontrak menjadi asas hukum yang bersifat universal. Di samping itu asas kebebasan berkontrak sebagai perwujudan atas pengakuan hak asasi manusia. Kata kebebasan sendiri memiliki dinamika perkembangan yang berjalan secara terusmenerus dalam sejarah panjang manusia. Bebas ditambah awalan ke dan akhiran an mengandung pengertian suatu keadaan di mana tiadanya penghalang atau pembatas, paksaan atau halangan, beban atau kewajiban.

Menurut Frans Magnis-Suseno kebebasan terbagi menjadi dua jenis yaitu, kebebasan eksistensial dan kebebasan sosial. Adapun yang dimamksud dengan kedua jenis tersebut. Kebebasan eksitensial adalah kebebasan dalam arti kemampuan manusia menentukan tindakannya sendiri. Sedangakan, kebebasan sosial adalah kebebasan yang diterima dari orang lain. Untuk itu kedua kebebasan ini merupakan sebuah kesatuan yang utuh dari kebebasan yang dimiliki manusia. Dua kebebasan tersebut tidak dapat saling meniadakan Mekanisme kebebasan berkontrak dalam pembuatan suatu kontrak (akad) untuk melaksanakan pembiayaan di lembaga keuangan syariah atau perbankan syariah masih belum begitu jelas. Biasanya kebebasan berkontrak cenderung untuk nasabah yang daya tawarnya tinggi (high bargaining position), sementara untuk nasabah yang mempunyai daya tawar rendah (low bargaining position) pihak lembaga keuangan cenderung menggunakan kontrak standar yang telah dibuat dahulu oleh pihak lembaga keuangan (kontrak baku) (Setiawan, 1979: 10-11).

Perjanjian pembiayaan di perbankan yang bersifat baku (standar contract) senantiasa membebani nasabah dengan berbagai macam kewajiban, termasuk tanggungjawab atas risiko yang ditimbulkan selama perjanjian berlangsung. Kondisi ini menimbulkan kurangnya tanggung jawab di pihak bmt dan tanggung jawab tidak terbatas di pihak anggota. Kontrak baku memang sudah biasa digunakan dalam perjanjian pembiayaan di perbankan atau lembaga keuangan konvensional maupun di perbankan atau lembaga keuangan syariah. Ketika kontrak baku disandingkan dengan akad-akad pembiayaan yang berprinsipkan pada syariah yang memberlukan musyawarah dalam pembagian nisbah bagi hasilnya, maka akan didapati ketidak teraturan. Salah satu contohnya pada akad pembiayaan musyarakah.

Mekanisme dalam perjanjian standar yaitu perjanjian dibuat dan disodorkan oleh pihak kepertama kepada pihak kedua untuk dipakai tanpa memiliki hak mengoreksi. Sehingga pihak kedua hanya bersandar pada ketidaktahuan kecuali mau menerima ketentuan dari kontrak patnernya yang telah dituangkan dalam formulir perjanjian naku tersebut. Akibatnya, artian kesepakatan sebagai syarat suatu perikatan dalam Pasal 1320 Kitab Undang-undang Hukum Perdata telah tiada dalam perjanjian standar ini (Muhamad, 2005: 79). Terpenuhinya syarat 
perjanjian mengakibatkan bagi para pihak untuk melaksanakan sesuatu, yaitu memperoleh seperangkat hak dan kewajiban yang disebut prestasi. Di mana Prestasi itu meliputi perbuatan-perbuatan: Menyerahkan sesuatu, misalnya membagi hasil keuntungan pengelolaan usaha dari pembiayaan musyarakah. Melakukan sesuatu, misalnya menjalankan dan mengelola usaha musyarakah dengan baik. Tidak melakukan sesuatu, misalnya mengakhiri dan memutuskan kontrak tanpa ada kesepakatan dari kedua belah pihak.

\section{Penerapan Asas Kebebasan Berkontrak pada Akad Pembiayaan Musyarakah di KSPPS BMT Lariba Islamic Centre menurut Hukum Positif}

Secara yuridis, perjanjian memberikan kebebasan seluas-luasnya kepada masyarakat untuk mengadakan perjanjian yang berisi apa saja asalkan tidak melanggar ketertiban umum dan kesusilaan. Pihak yang mengadakan perjanjian diperbolehkan membuat ketentuan-ketentuan sendiri yang menyimpang dari pasal-pasal hukum perjanjian dan mereka diperbolehkan mengatur sendiri kepentingan mereka dalam perjanjian yang mereka adakan. Hal ini sesuai dengan asas kebebasan berkontrak yang disimpulkan dari pasal 1338 Kitab Undang-undang Hukum Perdata yang berbunyi "semua perjanjian yang dibuat secara sah berlaku sebagai undang-undang bagi mereka yang membuatnya". Dari kata "semua" dapat ditafsirkan bahwa setiap subjek hukum dapat membuat perjanjian dengan isi apapun, untuk itu ada kebebasan subjek hukum untuk menentukan bentuk perjanjian atau membuat perjanjian (Setiawan, 1979: 11).

Kebebasan berkontrak telah diakui dan dianut sebagai suatu asas di dunia pada umumnya. Sehingga asas kebebasan berkontrak menjadi asas hukum yang bersifat universal. Di samping itu asas kebebasan berkontrak sebagai perwujudan atas pengakuan hak asasi manusia. Kata kebebasan sendiri memiliki dinamika perkembangan yang berjalan secara terusmenerus dalam sejarah panjang manusia. Bebas ditambah awalan ke dan akhiran an mengandung pengertian suatu keadaan di mana tiadanya penghalang atau pembatas, paksaan atau halangan, beban atau kewajiban (Kamil, 2012: 147-149).

Freedem of contract atau biasa disebut sebagai asas kebebasan berkontrak berarti setiap orang dapat secara bebas untuk membuat kontrak tentang apapun, kapan pun dan di mana pun. Namun, bebas disitu bukan berarti bebas sebebas-bebasnya, kebebasan yang dimaksud yaitu bebas yang masih dibatasi oleh undang-undang. Artinya setiap orang yang membuat kontrak tetap harus memenuhi syarat sah nya perjanjian dan tidak melanggar hukum, kesusilaan dan ketertiban umum.

Setiap orang bebas membuat persetujuan apapun selain yang telah diatur oleh undang-undang, maka tidak menutup kemungkinan para pihak untuk membuat persetujuan-persetujuan yang tidak diatur oleh undang-undang. Persetujuan yang belum diatur oleh undang-undang mengenai hukum persetujuan bersifat menambah, yang artinya pihak-pihak dalam membuat persetujuan bebas untuk menyimpang daripada ketentuan-ketentuan tersebut dalam Burgerlikh Wetboek. Mengenai kebebasan pihak-pihak untuk membuat persetujuanpersetujuan diadakan beberapa pembatasan yaitu tidak boleh melanggar hukum yang bersifat memaksa, ketertiban umum dan kesusilaan.

Pada Pasal 1338 Kitab Undangundang Hukum Perdata mencerminkan asas kebebasan berkontrak bagi para pihak untuk menentukan isi kontrak. Artinya kedua belah pihak secara bersama-sama bersepakat, bernegosiasi menentukan isi atau klausul kontrak perjanjian. Akan tetapi kehadiran kontrak baku masih dipertentangkan apakah kontrak baku memenuhi asas kebebasan berkontrak atau tidak. Karena pada prinsipnya asas kebebasan berkontrak dalam suatu kontrak atau akad dapat tercapai apabila terdapatnya kemampuan daya tawar 
menawar yang seimbang, dengan tujuan untuk memberikan hasil yang adil, patut dan sesuai dengan kehendak masing-masing.

Pada umumnya, suatu perjanjian tidak terikat pada bentuk-bentuk tertentu. Para pihak bebas menentukan bentuk perjanjian yang diinginkan sesuai dengan asas kebebasan berkontrak. Bentuk perjanjian yang dapat dipilih oleh para pihak ada dua macam yang pertama yaitu perjanjian dalam bentuk lisan dan yang kedua yaitu perjanjian dalam bentuk tertulis. Perjanjian yang sering dipilih yaitu perjanjian dalam bentuk tertulis, hal ini disebabkan perjanjian yang tertulis memiliki kekuatan pembuktian yang lebih kuat dibandingkan dengan perjanjian dalam bentuk lisan saat terjadinya sengketa. Untuk perjanjian jenis tertentu, undang-undang mengharuskan bentuk-bentuk tertentu yang apabila tidak dipenuhi maka akan mengakibatkan batalnya perjanjian tersebut. dalam hal ini, perjanjian dalam bentuk tertulis tidak hanya berfungsi sebagai alat pembuktian semata, tetapi sebagai syarat untuk adanya (bestaanwaarde) perjanjian itu.

Perjanjian baku dalam praktiknya dapat merugikan pihak yang lebih lemah, sedangkan bila dilihat dari keabsahan berlakunya perjanjian baku dapat dilihat dari syarat-syarat subjektif dan objektif dari Pasal 1320 Kitab Undang-undang Hukum Perdata yaitu kesepakatan, kecakapan, hal tertentu, dan sebab yang halal. Ada dua syarat yang harus dipenuhi yang pertama dinamakan syarat-syarat subjektif karena mengenai orang-orang atau subjek yang mengadakan perjanjian, sedangkan syarat yang kedua dinamakan syarat-syarat objektif karena mengenai perjanjiannya atau objek perbuatan hukum yang dilakukan. Apabila syarat objektif tidak terpenuhi maka perjanjian itu batal demi hukum.

Pada hakikatnya syarat sah perjanjian ini, berhubungan dengan subtansi akad atau perjanjian karena subtansi akad atau perjanjian merupakan pilar terbangunnya sebuah akad yang tujuan pokok yang ingi dicapai dengan adanya akad yang dilakukan dan berpengaruh terhadap implikasi tertentu. Subtansi akad akan berbeda untuk masing-masing akad yang berbeda. pembiayaan musyarakah, dimana pihak pertama menyerahkan modalnya kepada yang lain untuk pengelolaan usaha dengan pembagian keuntungan sesuai dengan kesepakatan.

Mekanisme kebebasan berkontrak dalam pembuatan suatu kontrak (akad) untuk melaksanakan pembiayaan di lembaga keuangan syariah atau perbankan syariah masih belum begitu jelas. Biasanya kebebasan berkontrak cenderung untuk nasabah yang daya tawarnya tinggi (high bargaining position), sementara untuk nasabah yang mempunyai daya tawar rendah (low bargaining position) pihak lembaga keuangan cenderung menggunakan kontrak standar yang telah dibuat dahulu oleh pihak lembaga keuangan (kontrak baku).

Menurut hukum positif yang berlaku di Indonesia standar contract atau kontrak baku yang mengandung asas kebebasan berkontrak diperbolehkan asalkan tidak boleh melanggar hukum yang bersifat memaksa, ketertiban umum dan kesusilaan serta terpenuhinya syarat-syarat yang diperlukan untuk sahnya suatu perjanjian sesuai dengan Pasal 1320 Kitab Undangundang Hukum Perdata satu sama lain. Keduanya merupakan dua sudut dari kebebasan manusia.

\section{Perspektif Hukum Islam Terhadap Penerapan Asas Kebebasan Berkontrak pada Akad Pembiayaan Musyarakah di KSPPS BMT Lariba Islamic Centre}

Perspektif Hukum Islam Terhadap Penerapan Asas Kebebasan Berkontrak pada Akad Pembiayaan Musyarakah di KSPPS BMT Lariba Islamic Centre Imam presepektif Imam Asy-Syafi'i asas kebebasan berkontrak adalam fikih Islam mencakup dua aspek, yaitu pertama kebebasan mengadakan akad dan sisi keridhaannya (hurriyatu at-Ta'aqqud wa ridhaiyyatih), yang kedua yaitu, kebebasan mengadakan syarat dan sisi keridhaannya 
(hurriyatu al-Isytirath wa tartib atsar alAqd) (Supramono, 2009: 54).

Dalam mazhab Syafi i, suatu syarat dipandang sah dan valid bila syarat tersebut dikehendaki oleh akad atau bila di dalam syarat tersebut terkandung kemaslahatan dan telah menjadi kebutuhan masyarakat, khususnya pihak-pihak yang terlibat dalam akad. Seperti khiyar, penentuan batas waktu, gadai dan sebagainya adalah boleh (tidak batal) meskipun tidak dikehendaki oleh akad karena hal itu dibutuhkan dan menjadi hajat manusia (Al-Zuhayli, 1989: 192).

Mazhab Syafi i dalam hal syarat yang dikehendaki akad. Bagi mazhab Syafìi syarat yang tidak dikehendaki akad tetap sah jika mengandung kemaslahatan dan menjadi kebutuhan masyarakat. Hal ini mengindikasikan bahwa mazhab Syafi`i progresif, karena mereka memasukkan unsur kemaslahatan dan kebutuhan masyarakat sebagai legalitas. Khusus dalam masalah kontrak, setiap individu berkeinginan aturan yang mengaturnya, agar tidak terjadi perbenturan antara kontrak yang satu dengan yang lainnya. Pihak BMT juga sudah memenuhi syarat dan ketentuan keabsahan sebuah akad, di mana di dalamnya terdapat kerelaan diantara kedua belah pihak, dan adanya kebebasan dalam memilih. Sudah bukan rahasia lagi, terkadang dalam sebuah kontrak kadang kala berpotensi terjadinya tindakan yang merugikan salah satu pihak hingga dapat menjebak salah satu atau bahkan keduanya menuju meja hijau, dan demikianlah yang menjadi kekhawatiran masyarakat terkait mengadakan kontrak dengan mitranya.

Kebutuhan

mengharuskan masyarakat mengadakan kontrak dengan pihak BMT yang dianggap dapat membantu. Kesepakatan dinyatakan sah apabila terdapat syarat objektif dan syarat subjektif. Syarat objektif berkaitan dengan bentuk akad dan sebab-sebab yang dihalalkan oleh syari'at, sementara syarat subjektif adalah terkait kesepakatan yang mengikat pihak-pihak yang terikat kontrak dan kecakapan dalam membuat syarat dan kontrak itu sendiri. Akan tetapi, ketentuan tersebut tidak dapat direalisasikan secara menyeluruh, pihak BMT dalam membuat isi perjanjian akad musyarakahnya tidak melibatkan anggota sebagai pihak kedua, karena sudah ditetapkan sebelum pihak kedua (anggota) ingin mengikatkan diri mereka dengan BMT Lariba Islamic Centre. Hal ini tidak menjadikan syarat dan akad perjanjian musyarakah yang telah ditetapkan pihak BMT menjadi tidak sah (batal), sebab menurut pandangan madzhab Asy-Syafi'i, selama sebuah akad mengandung kemaslahatan dan menjadi kebutuhan bagi masyarakat, serta tidak mengandung unsur merugikan kepada salah satu pihak tetap dianggap sah. Dalam proses kontrak tidak ada paksaan atau intimidasi terhadap pihak anggota. Sesuatu yang mendorong seorang melakukan sesuatu yang tidak diridainya dan tidak merupakan pilihan bebasnya. Hal ini juga dibuktikan dengan adanya kebebasan memilih untuk menjalankan kesepakatan atau menolaknya.

Jika dilihat melalui prosesnya sekilas sistem yang diterapkan oleh pihak BMT seperti sebuah kontrak baku, yaitu kontrak yang telah dibakukan klausul atau isinya. Sehingga anggota mau tidak mau jika ingin dibantu usahanya harus mengikuti syarat dan isi perjanjian yang diberlakukan oleh pihak BMT. Hal tersebut dianggap lebih meringkas waktu dan tidak perlu memakan waktu yang lama dalam pembuatan syarat dan isi perjanjian bersama anggota. Jika anggota menyatakan setuju dengan syarat dan isi perjanjian yang telah dibuat, maka anggota akan mendapatkan pembiayaan yang diharapkan, dan anggota akan terbantu. Dari sini peneliti memandang dalam akad atau perjanjian pembiayaan musyarakah yang diterapkan oleh pihak KSPPS BMT Lariba Islamic Centre secara sepihak, tidak dapat dikatakan kontrak baku. Sebab pihak KSPPS BMT Lariba Islamic Centre masih memberikan kebebasan pada anggota untuk negosiasi terhadap opsi yang ditawarkan. Sehingga akad/perjanjian tersebut tetap mengadung asas kebebasan berkontrak yang 
sama-sama mencapai kesepakatan setelah melakukan tawar-menawar atau negosiasi.

\section{KESIMPULAN}

Akad pembiayaan musyarakah yang diterapkan di KSPPS BMT Lariba Islamic Centre, pada dasarnya adalah sah karena telah terpenuhinya rukun dan syarat-syarat berkontrak dalam hukum Islam. Meskipun tidak memenuhi beberapa asas berkontrak dalam hukum Islam yaitu asas kebebasan berkontrak, asas kemaslahatan (tidak memberatkan) dan asas keadilan (keseimbangan), tidak menyebabkan akad kontrak pembiayaan musyarakah ini batal, dalam artian kontrak baku ini tetap sah untuk diterapkan, karena telah ada unsur saling ridha (sama-sama rela) di antara kedua belah pihak ditandai dengan ditandatanganinya kontrak pembiayaan musyarakah tersebut. Penerapan asas kebebasan berkontrak pada akad pembiayaan musyarakah di KSPPS BMT Lariba Islamic Centre Cirebon menurut hukum positif, keseluruhan sesuai menurut KUH Perdata dalam buku III pasal 1380 tentang kebebasan berkontrak dan telah mengemukakan bahwasannya dalam setiap klausul-klausulnya tidak melanggar hukum yang terdapat pada pasal 1380 KUHP Perdata tersebut. Pandangan hukum Islam terhadap penerapan asas kebebasan berkontrak pada akad pembiayaan musyarakah di KSPPS BMT Lariba Islamic Centre Cirebon, tidak terdapat klausul pembagian kerugian. Pembiayaan musyarakah dijelaskan bahwa kerugian harus dibagi di antara para mitra secara proporsional menurut modal masing-masing. Walaupun tidak ada pembagian kerugian di dalam klausul perjanjian kontrak tetap sah karena adanya antaradhin (suka rela).

\section{DAFTAR PUSTAKA}

Ahmadi, M. (2010). Hukum Kontrak Perancangan Kontrak. Jakarta: Rajawali Pers.

Al-Zuhayli, W. (1989). Al-Fiqh al-Islamiy wa Adillatuhu. Damsyik: Dar al-Fikr.

Anwar, S. (2010). Hukum Perjanjian
Syariah: Studi tentang Teori Akad dalam Fikih Muamalat. Jakarta: Rajawali Pers.

Djamil, F. (2013). Penerapan Hukum Perjanjian dalam Transaksi di Lembaga Keuangan Syariah. Jakarta: Sinar Grafika.

Ikhsanto, A. (2015). Studi Komparatif Asas Kebebasan Berkontrak dalam Jual Beli Menurut Kitab Undang-Undang Hukum Perdata dan Kompilasi Hukum Ekonomi Syariah. Jurnal Hukum Prodi Ilmu Hukum Fakultas Hukum Untan (Jurnal Mahasiswa S1 Fakultas Hukum) Universitas Tanjungpura, 3(1). Kamil, A. (2012). Filsafat Kebebasan Hakim. Jakarta: Kencana Prenada Media.

Khairunisa, R. (2018). Penerapan Asas Bebas Bekontrak dalam Akad Murabahah di BMT Al-Hasanah Sekampung. Skripsi, Fakultas Syariah IAIN Metro.

Muhamad. (2005). Manajemen Pembiayaan Bank Syariah. Yogyakarta: YKPN.

Raharjo, H., dan Seda, B. (2009). Hukum Perjanjian di Indonesia. Yogyakarta : Pustaka Yustisia

Rasyid, A. (2017). Asas Konsensualisme dalam Perspektif Hukum Positif dan Hukum Islam. Diakses dari https://businesslaw.binus.ac.id/2017/02/27/asaskonsensualisme-dalam-perspektifhukum-positif-dan-hukum-islam/

Rusydi, I. (2018). Asas Kebebasan Berkontrak dalam Pembiayaan Mudharabah pada Perbankan Syari'ah. Jurnal Ilmiah Galuh Justisi, 6(1), 91-106.

Safingi, A. (2009). Penerapan Asas Kebebasan Berkontrak Dalam Akad Pembiayaan di BMT Mitra Usaha Insani. Skripsi, Fakultas Syariah UIN Sunan Kalijaga Yogyakarta.

Salim, H. S. (2013). Hukum kontrak: Teori dan teknik penyusunan kontrak. Jakarta: Sinar Grafika.

Santoso, S. (2015). Penerapan Asas 
Kebebasan Berkontrak Pada Perjanjian

Pemborongan (Studi Kasus

Pelaksanaan Perjanjian Rehabilitasi

Jalan Simpang Sedayu, Kemusuk Lor,

Kecamatan Sedayu, Kabupaten Bantul).

Skripsi, Fakultas Syariah UIN Sunan

Kalijaga Yogyakarta.

Setiawan, R. (1979). Pokok-Pokok Hukum

Perikatan. Bandung: Bina Cipta.

Supramono, G. (2009). Perbankan dan Masalah Kredit. Jakarta: Rineka Cipta.

Syafei, R. (2001). Fiqih

Muamalah. Bandung: Pustaka Setia. 